\title{
THE INFLUENCE OF FOREIGN BANK ENTRY ON THE DEVELOPMENT OF REGIONAL FINANCIAL MARKETS
}

\author{
Anna Kladova ${ }^{1}$, Liudmila Parfenova ${ }^{2}$, Vytautas Juščius ${ }^{3}$ \\ Rosgosstrakh, Ltd. (Russia), Yaroslavl State University (Russia), Klaipėda University (Lithuania)
}

\begin{abstract}
Intensive international activity of banks caused by fairly recently lifted financial restrictions in many countries has been a subject of great scientific interest ever since. The article describes various short-term consequences of foreign bank penetration in the financial markets of some of the regions of the world. The authors pay specific attention to the reasons and modes of foreign bank entry in emerging market and transition market economies as well as to the differences in the impact of such entry on the stability and efficiency of financial systems and economies of the countries of Asia, Latin America, Central and Eastern Europe and Russia. Research methods: systemic, comparative and logical analysis.

KEYWORDS: foreign bank entry, emerging market economies, bank competition, banking sector stability.
\end{abstract}

JEL CODES: G21, G32

\section{Introduction}

Intense globalization of the world economy is an objective reality of the $21^{\text {st }}$ century. The process of globalization presupposes financial liberalization of national economies. Financial liberalization minimizes the government's role in the financial sector letting market forces independently determine the ways and areas of resources' distribution in that sphere. Banking market liberalization is a crucial part of financial liberalization.

Intensive foreign bank penetration has been one of the main trends of international finance development in the past two decades. The banks were particularly interested in conquering the freshly opened banking markets of such regions as Asia, Latin America, Central and Eastern Europe as well as the markets of the former Soviet Union republics, especially Russia. The reasons and modes of entry varied from region to region depending on many factors. The effects caused by the penetration also differed significantly, bordering on the opposite. The impact was especially strong on the condition of bank competition, on the welfare of local banks as well as on the access to credit for small and medium enterprises.

The purpose of this article is to compare the influence of foreign bank penetration on the development of financial, especially banking, markets in different regions of the world. The primary question to be ans-

\footnotetext{
Anna Kladova - Branch of Rosgosstrakh, Ltd in the Yaroslavl region, chief lawyer of the subrogation group. Scientific interest: bank competition, financial markets in EME countries.

E-mail: ryzhinka@gmail.com

Tel.: +79036916272.

2 Liudmila Parfenova - dr. Yaroslavl State University, dean of the Economic Department, head of the chair of finance and credit, professor. Scientific interest: international finance, European economic integration.

E-mail: decan@econom.uniyar.ac.ru

Tel.: +74852303344.

3 Vytautas Juščius - dr. Klaipeda University, Faculty of Social Sciences, head of the Economic Department, professor. Scientific interest: Corporate social responsibility, globalization.

E-mail: ek.smf@ku.lt

Tel.: +370 46398677 .
} 
wered in this article is whether the financial sectors in Asia, Latin America, Central and Eastern Europe and Russia reacted in the same way to the entry of foreign banks in the past decades. In order to fulfill this task, results of numerous empirical studies of foreign bank entry will be compared.

The objectives set for the research are:

- To define the key reasons of foreign bank penetration as well as the merits and flaws of the process.

- To identify specifics of foreign bank entry into the liberated markets of Asia, Latin America, Central and Eastern Europe and Russia correspondingly.

Research methods: systemic comparative and logical analysis.

\section{The basic determinants and short-term effects of foreign bank entry}

Since the 1960s international activity of banks has been growing steadily due to the development of international trade flows, foreign direct investment and the process of globalization of capital markets. There are two main types of such activity: performing cross-border operations and activities of banks outside of their home country (Lensink, 2003: 2). The latter has been a subject of strong scientific interest for more than a decade because of the rapid growth since the late 1990s of the presence of foreign bank capital in banking sectors of numerous countries, especially in emerging market and transition market economies. Prior to the wave of financial liberalization in the 1990s, countries often used various policies to restrict entry of foreign banks. Such policies reflected the governments' strong hesitation to open their national financial markets to competition from abroad.

On average, across developing countries, the share of bank assets held by foreign banks has risen from 22 percent in 1996 to 39 percent in 2005 (Cull, 2010: 2). Such intensive foreign bank expansion is mainly due to considerable financial liberalization carried out in developing countries which implies lowering or eliminating entry barriers to the banking markets of those countries.

However, the increase of foreign bank presence in the banking markets of various regions of the world has been uneven. Thus, the share of the banking system's assets controlled by foreign banks in the transition economies of Central and Eastern Europe as well as in the emerging market economies of Latin America has been growing steadily, reaching a rather high average level (52 percent and 50 percent correspondingly), while foreign bank participation has remained constant at very low levels in South Asia (7.5 percent). In East Asia foreign bank entry has increased since the mid-1990s, but it still represents less than 20 percent of the system (Cull, 2010: 3).

There are two basic approaches to defining the determinants of such aggressive expansion of foreign banks: the "follow the customer" hypothesis and the eclectic theory (Fotopoulos, 2011: 15). According to the former, foreign banks are driven by passive, defensive motives and penetrate the markets of emerging and transition economies in order to follow the expansion of their non-financial clients from the home country. In this case the banks intend to retain their relationships with domestic clients abroad. The potential of the penetrated banking sectors in such situations is usually insignificant for the banks.

The eclectic theory, on the other hand, states that the previous hypothesis alone is not able to fully account for the phenomenon and should be amplified with more aggressive motives. Therefore, according to the theory, foreign banks choose to penetrate a certain bank market not only to follow their domestic customers but also to expand their own business and raise their profits. The key determinants of the penetration in this case include three groups of factors (see figure 1).

This approach has been gaining more and more support in the empirical literature throughout the last decade. Various kinds of research carried out in different regions of the world have proven that the eclectic theory offers a more accurate and complete explanation of the reasons which make the foreign banks choose a certain country or a certain group of countries as an area for foreign direct investment (Focarelli, 2001: 4; Fotopoulos, 2011: 16). At the same time, each foreign bank extends the realm of its activity for an individual set of those reasons, depending on the bank's final goals.

The banks which penetrate foreign markets, as a rule, have certain traits in common. For instance, such banks are usually rather large and effectively managed ones. Besides, they are located in the open to interna- 
tional trade countries with highly developed banking systems. The profitability and the share of non-interest over total income of such banks are usually higher as well (Pozzolo, 2008: 4). Thus, the most successful banks in their home countries are the ones most prone to foreign direct investment.

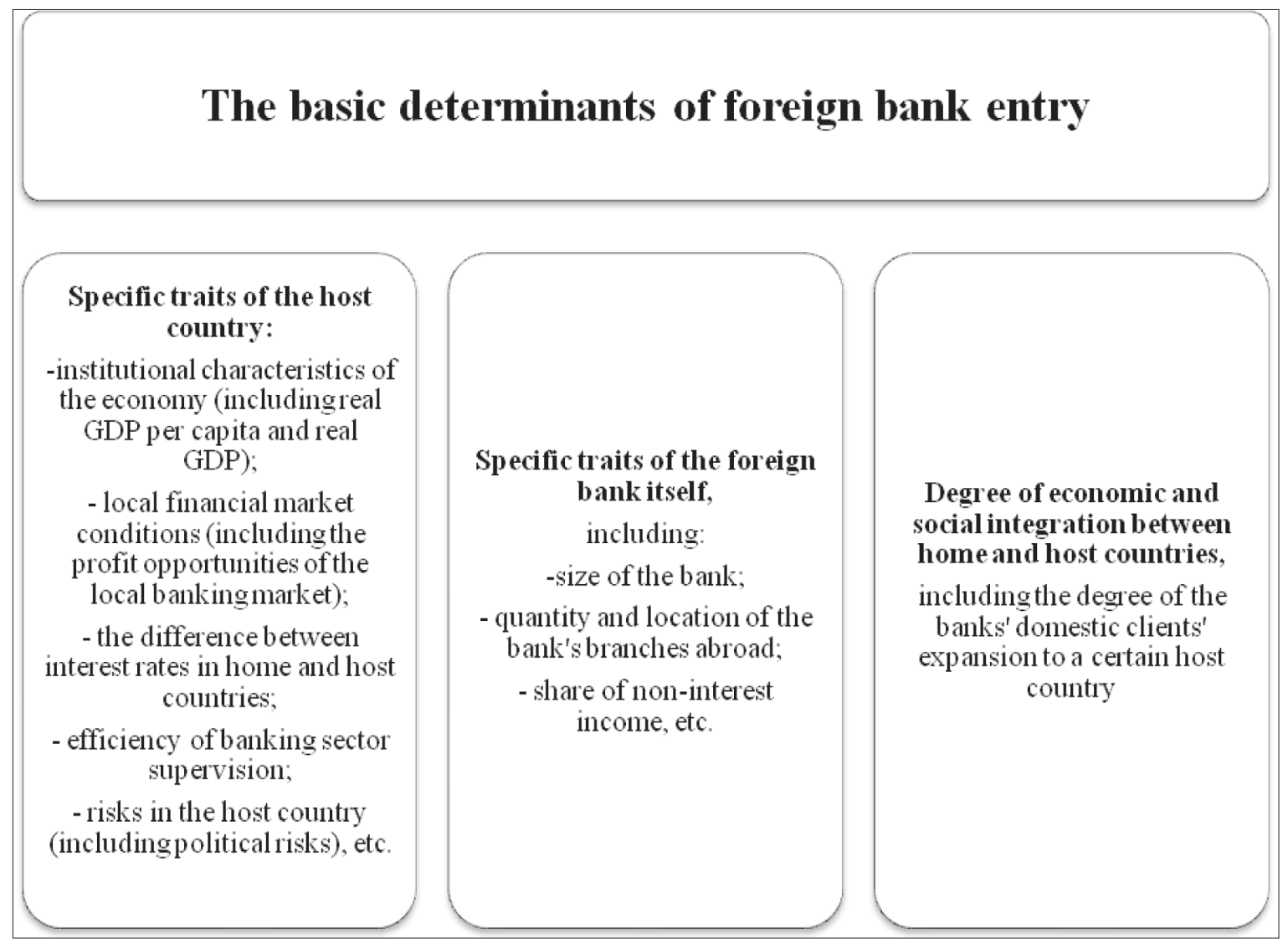

Figure 1. The basic determinants of foreign bank entry

The ways in which foreign banks penetrate national banking markets vary significantly from a classical "de novo" entry or mergers and acquisitions of domestic banks to even taking part in a privatization of stateowned local banks. The mode foreign banks choose to use in order to enter a market of a certain country, in many respects, determines the impact such penetration might cause on the economy of the host country.

The presence of foreign capital in a national banking market is commonly viewed as a phenomenon causing positive consequences for both the banking sector and the economy of the host country, in general. However, thorough research of the impact of foreign bank expansion on national economies of a considerable number of countries has revealed certain negative effects of growing non-residents' control of the assets of national banking systems. A review of foreign bank penetration's benefits and drawbacks usually covered in theoretical and empirical studies is presented in table 1.

It should be noted that the advantages and drawbacks described in table 1 are viewed as short-term effects because the time-series of banking activities in the emerging and transition economies are rather short making it difficult for a scientist to analyze any long-term effects of the process of foreign bank expansion. Therefore, all estimations interpreted as short-term effects of foreign banks entry may significantly differ from long-term results of such activity (Liuhto, 2006: 41).

The countries the banking markets of which have been the objects of the most intensive foreign bank penetration differ greatly in terms of geography, demography, politics and economy. Those differences have caused certain specificity of the process and its results in such regions as Latin America, Asia, Central and Eastern Europe and Russia. 
Table 1. Benefits and drawbacks of foreign bank penetration

\begin{tabular}{|c|c|c|}
\hline Object of influence & Benefits & Drawbacks \\
\hline $\begin{array}{l}\text { Financial system and } \\
\text { economy of a host } \\
\text { country }\end{array}$ & $\begin{array}{l}\text { 1. Increase in the host country's banking } \\
\text { sector's efficiency due to the import of } \\
\text { new banking technologies, products and } \\
\text { management techniques. } \\
\text { 2. Increase in bank competition. } \\
\text { 3. Increase in the country's banking sector's } \\
\text { stability. Subsidiaries of foreign banks are } \\
\text { less sensitive to crises taking place in the } \\
\text { host country due to their better access to } \\
\text { financial resources from abroad and their } \\
\text { more diverse loan portfolios. } \\
\text { 4. Increase in the country's banking sector's } \\
\text { capitalization, which is an especially urgent } \\
\text { issue in times of a crisis. } \\
\text { 5. Increase in the country's banking } \\
\text { sector's profitability due to the economy of } \\
\text { scale. Foreign banks are able to stimulate } \\
\text { the process of the country's banking } \\
\text { sector consolidation since they usually } \\
\text { possess enough knowledge and practical } \\
\text { experience of performing other types of } \\
\text { financial services, i.e. insurance, brokerage } \\
\text { services, etc. } \\
6 . \text { Financial market's development. Foreign } \\
\text { bank entry is able to stimulate the host } \\
\text { country's interbank market's progress and } \\
\text { attract the clients, who otherwise might } \\
\text { have used the services of banks in other } \\
\text { countries. } \\
\text { 7. Improvement of the financial sector's } \\
\text { infrastructure due to the import of the } \\
\text { banks' experience of rendering high quality } \\
\text { services, the banks' know-how, accounting } \\
\text { practices, etc. } \\
8 \text {. Mobilization of foreign direct investment }\end{array}$ & $\begin{array}{l}\text { 1. Danger of a foreign country's control. An } \\
\text { ability to control allocation of loan resources } \\
\text { implies possessing fairly significant economic } \\
\text { power in any type of economy. } \\
\text { 2. Contradiction between the interests of } \\
\text { foreign banks and the host country. Foreign } \\
\text { banks may be interested solely in promoting } \\
\text { their compatriot exporters or in providing } \\
\text { services to the projects carried out by the } \\
\text { customers from their home country. } \\
\text { 3. Differences between the home and the host } \\
\text { countries' regulations. The home country's } \\
\text { authorities lose their regulatory control over } \\
\text { the foreign bank's branch abroad. Therefore, } \\
\text { if the banking sector's regulations in the host } \\
\text { country are weaker and less efficient, foreign } \\
\text { banks might engage in riskier and more } \\
\text { negligent operations. } \\
\text { 4. Reduction in margins, profitability and } \\
\text { overall expenses of domestically owned banks. } \\
\text { 5. Less access to credit for small and medium } \\
\text { enterprises. } \\
6 \text {. Danger of financial crises in foreign banks' } \\
\text { home countries spilling over into the host } \\
\text { countries }\end{array}$ \\
\hline $\begin{array}{l}\text { Domestic banks } \\
\text { purchased by foreign } \\
\text { banks in the course of } \\
\text { expansion }\end{array}$ & $\begin{array}{l}\text { 1. Obtaining letters from parent banks } \\
\text { guaranteeing financial support of the } \\
\text { branch in case of a crisis in the host country. } \\
\text { 2. Easier access to relatively cheap foreign } \\
\text { sources of funding }\end{array}$ & $\begin{array}{l}\text { 1. Problems with putting guarantees of support } \\
\text { to practice. Parent banks' written guarantees } \\
\text { of financial support are often nothing more } \\
\text { than "comfort letters" representing only moral } \\
\text { commitment. } \\
\text { 2. Limited access to foreign sources of funding } \\
\text { outside of the parent bank. Quite often parent } \\
\text { banks reduce operational costs by closing } \\
\text { its branch's foreign funding channels and } \\
\text { becoming its only source of financial resources } \\
\text { abroad. Such actions make the branch more } \\
\text { dependent on the willingness of the parent } \\
\text { bank to provide funding in stressful situations } \\
\text { and, thus, make it weaker and more vulnerable } \\
\text { in times of crises }\end{array}$ \\
\hline
\end{tabular}

Source: Compiled by the authors based on (Gardenas, 2004; Liuhto, 2006) 


\section{The influence of foreign bank entry in Asia}

India is one of the countries of Asia in which the drawbacks of foreign bank penetration are most apparent. Up to 1991 the economy of India, in general, and its financial sector were strictly regulated by the state which dominated in most of economic sectors. As a result of the 1991 balance of payments crisis, India has conducted a series of structural reforms in order to raise its banking sector's competitiveness. In the course of those reforms India has granted foreign banks entry into its national market on a condition of only entering it "de novo" - purchasing controlling interest of domestic banks was strictly prohibited.

Rapid foreign banks expansion which followed the liberalization of Indian financial market, despite any expectations, had a negative impact on the condition of the country's banking sector. First of all, foreign banks mostly penetrated urban areas almost completely ignoring poor and rural parts of the country. Furthermore, since the start of the expansion the total number of bank branches has declined, particularly in the rural areas (Singh, 2006: 1).

Besides, the country experienced a systematic decline in domestic banks' lending. According to empirical research, such decline appeared to be supply-driven rather than demand-driven. On average, Indian firms were 7.6 percentage points less likely to have a long-term loan of any size following the entry of a foreign bank (Gormley, 2007: 4). In spite of the fact that small and medium enterprises in India constitute about 40 percent of the country's total production, approximately 30 percent of exports and are the country's second largest employer after agricultural businesses, the most rapidly growing segment of Indian banking market nowadays is consumer retail loans. Foreign banks concentrate on rendering "exclusive banking" services to wealthy and affluent, according to Indian standards, clients who can afford a minimum balance of US\$5000 in their accounts with the bank (Singh, 2006: 3 ).

Thus, the objectives of foreign banks in India differ fundamentally from the initial goals pursued by the state during the liberalization reforms. Due to this fact, the colossal need in bank services of the large part of Indian population living in rural and poor areas is getting stronger while the efficiency of the country's banking sector is dropping dramatically.

While foreign bank entry into Chinese financial markets has started later than the one in India, it has been no less impetuous and has caused partly similar impact on the financial sector of the country. On December 11, 2001, China gained entry into the World Trade Organization (WTO). The pressure from WTO forced China to abandon its initial strategy of limited financial liberalization. As a result, foreign banks were granted permission to conduct all types of foreign exchange transactions with foreign clients immediately upon accession of China to the WTO. The geographical restrictions on local currency business of foreign banks were phased out over five years; four cities were open upon accession, four additional ones - thereafter. Foreign strategic investment started in China in 2001, when the International Financial Corporation (IFC), the private sector arm of the World Bank Group, first purchased 7 percent of stakes in the Bank of Shanghai, a city commercial bank in China (Hasan, 2012: 6).

Within two years after accession, China permitted foreign banks to provide local currency services to Chinese enterprises. In December, 2003 the "ceiling" on foreign ownership in Chinese banks was raised from 15 percent to 20 percent for a single bank and to 25 percent overall. Mergers and acquires were also encouraged. Thus, while in most other countries, foreign investment took the form of direct takeovers or majority shareholding, foreign investment in China's banks has taken the form of minority shareholding with very limited ownership involvement.

Within five years of China's accession into the WTO, the country was obliged to eliminate all current non-prudential measures regarding the ownership, operation and establishment of foreign banks, as well as those concerning their branches and restrictions on issuing licenses (national treatment).

One of the major attraction points for the foreign banks was the size of personal savings in China, exceeding a trillion US dollars in 2005. Besides, the banks preferred to penetrate the coastal regions and cities of China, where the bulk of the country's banking was concentrated (Singh, 2006:2). According to the Almanac of China's Finance and Banking, the number of greenfield ("de novo") banks had increased close to 600 by 
the end of 2009, almost three times of that in 2001. According to the Annual Report of China Banking Regulatory Commission (CBRC), 31 Chinese commercial banks had introduced foreign strategic investors by the end of 2009 (Huang, 2011: 814).

By the end of 2010, banks of 14 countries or zones have set up 37 foreign-owned banks (including 223 branches), 2 joint-owned banks (including 6 branches and one subsidiary body) and one foreign-owned finance company. There are 74 foreign banks of 25 countries and zones which set up 90 branches. There are 360 operational institutions totally, almost doubling that of 2004. Total asset of foreign banks in China is twice more than that in 2004 and is 1.85 percent of total asset of financial institutions of Chinese banking sector (Li, 2011: 1).

The banking sector of China in general benefited from foreign bank expansion, e.g. recent research has shown that introduction of foreign strategic investors has had a positive effect on the promotion of profit efficiency of Chinese commercial banks (Li, 2011: 7). Indeed, the opening up of Chinese banking sector has posed no immediate threat to the four large state-owned banks because of their vast branch networks in both urban and rural areas. However, the principal losses of foreign capital expansion in China, as well as in India, were suffered by small and medium banks providing a major share of lending to small and medium enterprises. Considering the fact that such enterprises are the engines of China's economy, a decline in loans in this sphere might have negative repercussions on the economic growth of the country in the future.

In this case, even various microcredit programs - quite a widespread phenomenon in India - are not able to substitute for the formal banking industry because they only cover a small fraction of the under-banked population. Considering that such credit is often used on everyday consumption purposes, microcredit programs are not capable of satisfying the growing credit needs of farmers, rural entrepreneurs and small businesses. As for China, these kinds of programs do not exist there on a major scale.

At the same time, extensive empirical research of the banking sector in Bangladesh had shown that the danger of losing market share is coming not from foreign penetration, at least in the short run, but from the reasons within the country, including the low quality of loans and poor borrowers' discipline. If this problem is solved, foreign bank entry will have a positive impact on Bangladeshi banking market by introducing the advanced banking technologies and increasing operational efficiency of domestic banks (Raihan, 2000: 14).

The results of foreign bank entry into the national markets of emerging economy countries of Asia corroborate the theories of bank competition that take into account information asymmetries in the banking industry. According to those theories, stronger competition in banking sectors in conditions of information asymmetries may make access to credit much more difficult for certain firms. In less developed countries, foreign banks enjoy easier access to funding; however, their access to information is usually limited in comparison with domestic banks. High costs of obtaining information about domestic firms may force foreign banks to follow the strategy of "cherry picking" - providing loans to the most profitable and opaque companies. As a result, foreign banks compete domestic ones away from some segments of the market as well as drive less attractive and opaque companies off domestic banks thereby reducing credit access to firms in these spheres (Gormley, 2007: 4).

\section{The influence of foreign bank entry in Latin America}

One of the specific features of foreign bank penetration in the financial markets of Latin America, which started in the mid-1990s, was the fact that it was mostly accomplished not in "de novo" mode but through the purchase of distressed banks during crises (Yeyati, 2007: 1635). This is especially true for Mexico, where non-residents have gained control over 83 percent of the banking sector's assets and the top five banks have been acquired by foreigners by 2005 (Beck, 2007: 1). The degree of some of the foreign banks' presence in certain segments of Mexican banking sector is even more impressive. For example, by 2004 the share of foreign banks in derivatives operations has exceeded 90 percent (Gardenas, 2004: 3).

Besides, the determinants of foreign, especially European, bank entry into some of the banking markets of the region are also rather specific. For example, the desire of the Old World's banks to operate in Brazilian 
banking market was based on two key motives. Some banks grew substantially by following merger and acquisition-based expansion strategies in their domestic markets with a view to positioning themselves as leaders there. This policy allowed them to increase their competitiveness and grow large enough to expand internationally. Thus, after consolidating their position in the domestic market they extended their operations abroad. Others, on the contrary, themselves being large banks in highly concentrated small or medium sized systems, increasingly expanded their operations to other geographical markets, since domestic alternatives were limited (Rodrigues de Paula, 2003: 175).

It should be noted that Brazil's policy on permitting foreign bank entry into its banking market has been very selective compared to other large Latin American countries. Such selectiveness has prevented Brazilian domestic private-sector banks from being "swallowed up" by foreign ones. As a result, private sector domestic banks are still hegemonic in Brazil compared to foreign ones. The events in Argentina in 2001 and 2002 demonstrate the problems that an economy faces during an economic and financial crisis when the financial system of the country is dominated by foreign banks. Besides, the unwise measures taken by the government of Argentina at the time forced foreign banks not to recapitalize their sinking subsidiaries in the country which aggravated the consequences of the crisis (Gardenas, 2004: 9).

On the whole, foreign bank entry into the markets of Latin America has caused a decrease in the level of bank competition in the region but at the same time its influence on the national banking sectors' stability and efficiency was positive. However, in Mexico, while the share of municipalities served by foreign banks increased along with the rise in foreign bank participation, branch penetration fell for all banks in the system. The rural and poor districts where the ones to suffer the greatest decline in the banking services coverage. Deposits and loans per capita dropped for banks that became foreign and for Mexico as a whole, given the fact that the five largest and most important banks in the system became foreign-owned. The decline in loans was only partially offset by the behavior of domestic banks which seemed to lend more as the foreign presence in the market grew (Beck, 2007: 19). Therefore, although the general depth of bank branch penetration in Mexico seems to have increased, the chances of a bank branch opening in a certain district becomes a reality only in rich urban municipalities.

Scientists believe that the different impact of foreign bank entry on the levels of bank competition and efficiency in different host countries depends on the situation in the host country's banking market. Various studies on the subject suggest that foreign bank entry can bring potential gains in this area except in environments that limit competitive forces, such as when bank concentration is high, bank activities are restricted, and bank entry and exit is difficult (Beck, 2007: 2). Besides, foreign direct investment influences financial markets of emerging economies and industrialized countries differently. In emerging economies, subsidiaries of foreign banks enjoy higher interest rate margins and profitability than domestically owned banks, whereas in industrialized economies the opposite is true. This effect on markets may stem from both the actual entry of new competitors, as well as be a consequence of the increased likelihood of new entries to the industry in pursue of high profits (i.e. market contestability). These contrasting results could be explained by the different origin of the mergers and acquisitions which take place in emerging economies and industrialized countries. Foreign bank entry in emerging economies has been the result of dealing with financial crises, while in mature economies foreign entry comes from competitive pressures. In contrast with industrialized countries, cross-border mergers and acquisitions in Latin America have led to an almost universal increase of bank concentration indices (Gardenas, 2004: 3).

\section{The influence of foreign bank entry in Central and Eastern Europe}

Multinational banks' intensive participation in the development of transition economy countries became especially apparent since the dawn of the 1990s. The banks' choice of a host country for their foreign direct investment was usually based on the similar institutional and legal systems, common history, language and geographical proximity of the two countries. It is not surprising, therefore, that 60 percent of foreign banks in 
Latin America came from the USA and Spain, while 90 percent of non-resident banks in Central and Eastern Europe came from within the EU (Miklaszewska, 2009: 57).

The scale of the penetration was truly tremendous. In 1995, foreign bank assets constituted about 5 percent of total bank assets of the region, while by 2006 they exceeded 80 percent. In Poland, as in other countries of the region, a dramatic inflow of foreign bank capital took place in pre-EU accession period: between 1998 and 2000 the share of foreign bank assets in the total bank assets of the country increased from 17 to 70 percent (Miklaszewska, 2009: 59). Currently, foreign banks own more than 50 percent of the equity capital of banks in Central and Eastern Europe. In some of those countries, such as Estonia, Bulgaria, the Czech Republic, Slovakia, foreign banks control up to 80 percent of the banking markets (Liuhto, 2006: 41). Such dominance in the banking markets of the region in most cases has led to creating stable banking sectors, at least from the institutional point of view (Gorshkov, 2011: 2).

The reasons of EU banks' entry into the markets of some of the transition economies included high potential of those countries' economic growth, attractive prospects of the countries' profitability growth upon their accession into the EU as well as efficient reforms carried out by the governments. Due to these reasons, the principal mode of foreign bank entry into the markets of the Central and Eastern countries was purchasing a controlling share of an already established bank (either by participation in privatization processes or buying a controlling stake in publicly traded banks) or by purchasing a license from a small local bank and converting it into 100 percent foreign-owned daughter company of a global bank. As a result of such operations, currently most of the largest banks in the region are at least partially, but usually 100 percent foreign-owned.

In contrast with the influence of foreign bank entry in Latin America, the process has led to an increase in bank competition in the banking markets of the Central and Eastern European transition economies. The impact on loans and interest margins of domestic banks in the region, however, was not uniform. In particular, when the foreign banks entering national banking markets were comparatively larger than the domestic ones, the latter due to the increasing competition had to offer their clients better loan conditions and, as a result, suffer increasing loan losses. Besides, larger foreign banks were able to achieve certain economy of scale. In other cases, foreign bank penetration did not have such a significant impact on the subject (Liuhto, 2006: 53).

The consequences of foreign bank entry into the banking markets of transition economies depended greatly on the banks' mode of entry. Mergers and acquisitions of domestic banks by the non-residents led to virtual extinctions of the former and resulted in the decline in domestic loans. At the same time, the entry of foreign banks via greenfield investment (de novo) was associated with higher rate of firm creation in more opaque industries - a sign of market segmentation where greenfield foreign banks attracted transparent borrowers and, thus, intensified competitive pressure on domestic banks to increase their supply of loans to small and medium enterprises. Nonetheless, foreign bank entry into the financial markets of the region has decreased the access of small and medium companies to credit and, therefore, has led to lower rates of firm entry and higher rates of firm exit in opaque industries in relation to more transparent industries (Havrylchyk, 2011: 17).

Empirical research of the short-term effects of foreign bank entry on bank performance in the Central and Eastern European countries has also shown that in countries with less developed banking sectors foreign bank capital expansion leads to the growth of overhead costs associated with the need to upgrade the sector's technological level. These results have corroborated "the technology gap hypothesis", according to which the size of the technological gap between foreign and domestic banks determines the degree to which foreign bank expansion influences the size of domestic banks' overhead costs (Liuhto, 2006: 56).

\section{The influence of foreign bank entry in Russia}

Quite active penetration of foreign bank capital into the banking sector of Russia, which became especially prominent in the 2000 s, was determined both by the specifics of the economic situation in the country and by Russia's expanding international relationships. The motivation behind foreign direct investment in Russia coincided, for the most part, with the reasons of foreign bank penetration in Latin America. One of the few exceptions was the lack of need to escape from domestic financial regulations, growing competition or 
a dramatic decline in profits in home countries. Mostly, the desire to cooperate with Russia was determined by political interactions and historical ties between Russia and some of the home countries of the foreign banks. In particular, this is true for such banks as Bank of China, bank of Scotland, some French banks, etc.

In many cases, the growth of non-residential presence in the banking sector of Russia was accounted for by high economic development rate. The rapid way in which Russian economy grew in the 2000s managed to attract some prominent foreign non-financial companies. In order to maintain the bank-customer relationships, the banks from their home countries chose to follow their clients to Russia. This approach was particularly typical for many Japanese banks which were willing to support their clients in a new market by investing in big and significant projects. Deposits and bank retail were the least of their priorities. It is still true for most of the Japanese banks operating in Russia: they are less competitive and prefer to stick to the "main bank" features when they establish relationships with the clients. The reasons for such slow progress of Japanese banks in Russia include insufficient infrastructure development, lack of transparency of the country's economy as well as entry barriers in the banking sector.

Besides, there are certain factors (including macroeconomic and structural imbalances of the economy, etc.) which stipulate high potential banking profits in the banking market of Russia. Therefore, part of the motivation behind intensive foreign bank entry into this sector is so-called "high risk-high return" motivation. A desire to maintain an image of a global international bank is often also a part of the banks' motivation (Gorshkov, 2011: 8).

Theoretical and empirical literature on the subject describes four basic modes of foreign bank entry into the banking market of Russia: establishing a subsidiary bank (de novo entry), establishing a joint venture with a Russian domestic bank, minor shareholder participation and establishing a representative office in Russia. The last mode is often preferred by foreign banks despite the fact that such units have no right to perform banking operations. The purpose of establishing a representative office in Russia is collecting the necessary information about the market in Russia and providing domestic clients with it. As a rule, a few years later foreign banks convert the office into a subsidiary bank falling under the jurisdiction of Russia. Such step-by-step approach is caused by the serious preliminary work necessary to be done in order to establish a subsidiary, including being licensed by the Bank of Russia. Typically, foreign banks prefer to create 100 percent foreign-owned subsidiaries because of such issues as mistrust and low transparency level of property rights protection (Gorshkov, 2011: 10).

The product placement strategies used by foreign banks in the banking market of Russia include three basic types: universal strategy (multiproduct and multiclient), specialized strategy (monoproduct and monoclient) and combined strategy (either monoproduct and multiclient, or multiproduct and monoclient). The first strategy was especially popular before the financial crisis of 2008 both with foreign and domestic banks in Russia which resulted in gradual ejecting of domestic banks from certain segments of the market, including those of the basic mass market banking products and services (Mamonov, 2009: 185-186).

The number of foreign-owned, at least partially, banks registered in Russia has almost doubled during the period from 2001 to 2012 while the total number of banks in the country has been gradually decreasing since 2005 (see figure 2).

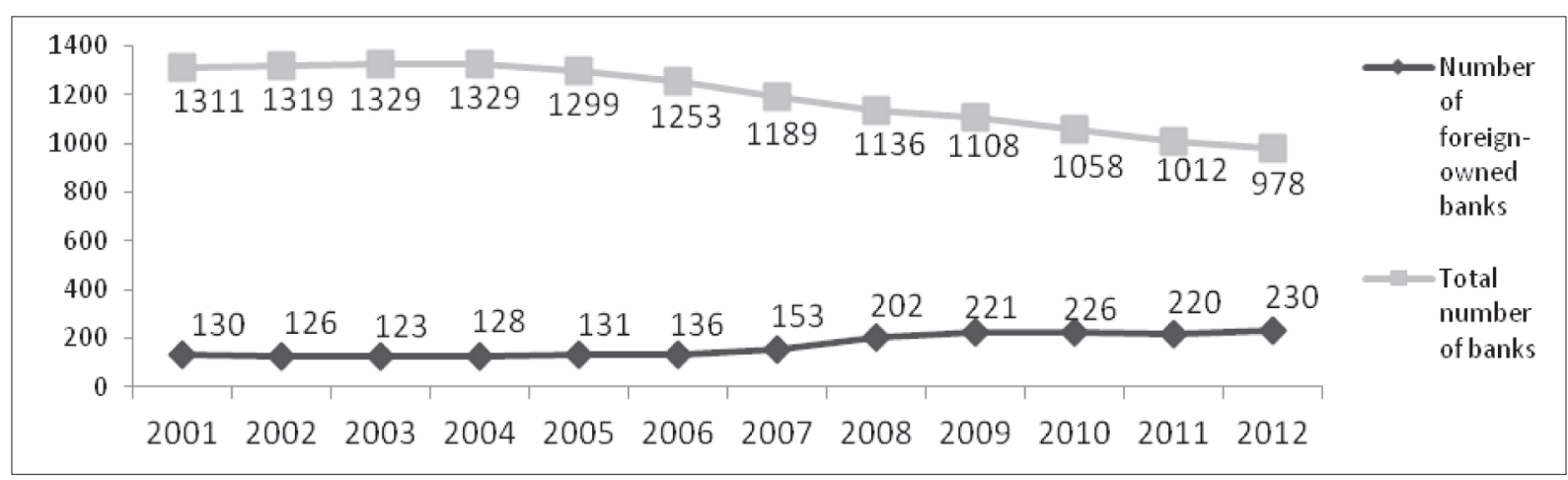

Figure 2. The number of foreign-owned banks and the total number of banks in Russia in 2001-2012

Source: Bank of Russia 
While the number of foreign-owned banks in Russia grew steadily in the last decade, the total degree of foreign participation in the country's banking sector kept decreasing. In 2003-2008, the share of non-residents in the total capital of the sector increased from 5.2 percent to 28.5 percent. However, it has shrunk to 28.1 percent by January, 2011 and to 27.2 percent by January, 2012. Besides, in the last two years the number of 100 percent foreign-owned banks in Russia has decreased from 82 to 77, while the number of their regional branches has gone from 242 to 155 (Bank of Russia).

Due to the recent financial crisis, serious shifts occurred in the group of foreign bank subsidiaries in Russia. The rate of growth of the banks aimed at traditional for their parent banks types of business was considerably high. At the same time, the banks which were excessively concentrated on new market niches before the crises were losing their positions and started to announce their full or partial exit from the banking market of Russia (Mamonov, 2011: 30).

In February, 2011 the largest world player in the agricultural loans market Rabobank Groep NV's subsidiary in Russia returned its license to the Bank of Russia. The bank couldn't compete with the state-owned mammoth - Rosselkhozbank, a monopolist in the agro-industrial segment of the country's banking sphere. The foreign stock-holders of five other subsidiaries sold 100 percent of their stock to the residents in 2011 (Bank of Russia).

According to thorough research, foreign bank expansion in Russia is a factor causing positive impact on the level of bank competition and, therefore, on the stability of the banking market in the country (Korobov, 2010: 16; Mamonov, 2010: 21). Besides, available empirical evidence for Russia shows that in the 2000s the margins of Russian domestic banks, both state-controlled and private ones, have been decreasing towards the level of margins in foreign-owned banks (Fungáčová, 2010: 15).

The decrease of foreign capital participation in the banking sector of Russia is one of the factors causing an increase in the industry's concentration levels and, therefore, a decline in bank competition. The systematic decline in the total number of banks operating in Russia was mostly a result of the drop of the number of banks in the Central federal district, while the number of banks in other federal districts was considerably stable up to 2010. Another proof of the growing concentration in the country's banking sector is the dynamics of $\mathrm{CR}_{5}$ and $\mathrm{CR}_{200}$ concentration ratios as well as those of the Herfindahl-Hirschman index (see figure 3).

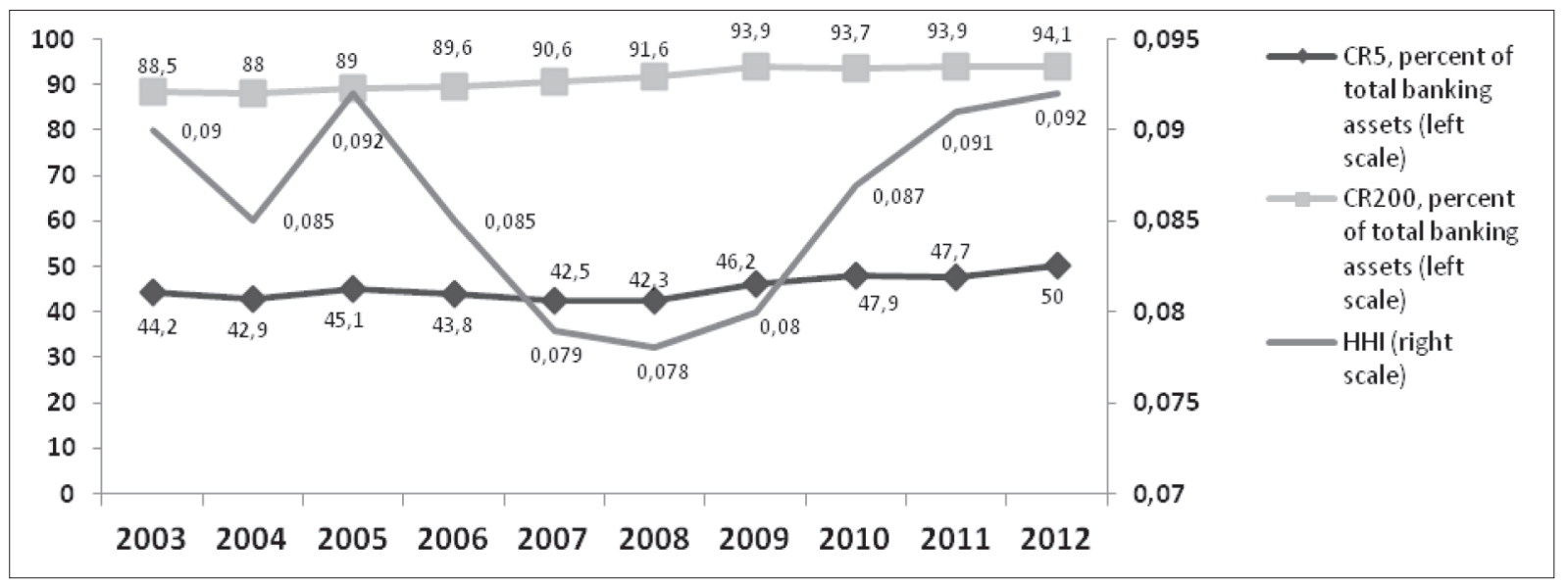

Figure 3. Concentration ratios and HHI for the banking sector of Russia in 2003-2012

Source: Bank of Russia

Various non-structural researches also attest to the fact that the level of bank competition in Russia has been decreasing due to the decline in foreign bank presence (Mamonov, 2010: 19). Insufficient levels of bank competition in the country may cause the raise of financial services' prices, limit the access of companies and individuals to credit and pose a threat to the banking sector's stability if the banks become too big to fail. In the current situation, Russia needs to find alternative ways of resisting the growth of bank market 
concentration in order to provide efficiency and stability of the market. A possible means of such resistance is regional consolidation which implies creating powerful regional financial institutions able to compete with state-owned banks, as a result of mergers and acquisitions of several small and medium regional banks.

\section{Conclusions}

A study of the influence of foreign bank entry into the banking markets of Asia, Latin America, Central and Eastern Europe as well as Russia has shown that this phenomenon causes different consequences in different countries depending on many factors. One of the chief determinants of the positive or negative "sign" of the expansion's overall influence is the host country's level of development, both in terms of economy, in general, and the banking sector, in particular. One of the most questionable "classic" results of foreign bank penetration seems to be its positive influence of the host country's level of bank competition. This turned out to be true only in Central and Eastern Europe and in Russia.

Active acquisition of domestic banks in Latin America has made the banking markets of the region more vulnerable to crises imported from abroad, while the stability of banking sectors in Russia and in the countries of Central and Eastern Europe has benefited greatly from the process. Such differences might have been caused by different potential of independent development characteristic for the banking markets of the latter regions. Besides, the fact that foreign bank entry in Latin America has been carried out during and as a result of financial crises, while the other regions were prospering during the process, might have also played a certain role in determining the different outcomes of the penetration.

\section{References}

Bank of Russia. Available at: http://www.cbr.ru

Beck, T., Martinez Peria, M. S. (2007). Foreign Bank Acquisitions and Outreach, Evidence from Mexico. Available at: http://www.imf.org/external/np/seminars/eng/2008/strureform/pdf/bkacq.pdf

Cull, R., Martinez Peria, M. S. (2010). Foreign Bank Participation in Developing Countries: What Do We Know about the Drivers and Consequences of This Phenomenon? Policy Research Working Paper, WPS5398.

Focarelli, D., Pozzolo, A. F. (2001). Where Do Banks Expand Abroad? An Empirical Analysis. Available at: http:// papers.ssrn.com/sol3/papers.cfm?abstract_id=301644

Fotopoulos, S., Siokis, F., Papapanagos, H. (2011). The determinants of the foreign banks' expansion in South Europe: Do Greek banks still follow their customers abroad or not? International Conference on Economics, Business and Management, IPED, Vol. 2, p. 15-19.

Fungáčová, Z., Solanko, L., Weill, L. (2010). Market Power in the Russian Banking Industry. BOFIT Discussion Paper, No. 3.

Gardenas, J., Graf, J. P., O’Dogherty, P. (2004). Foreign banks entry in emerging market economies: a host country perspective. Available at: http://www.bis.org/publ/cgfs22Mexico.pdf

Gormley, T. A. (2007). Banking Competition in Developing Countries: Does Foreign Bank Entry Improve Credit Access? Available at: http://fic.wharton.upenn.edu/fic/india/11gormley.pdf

Gorshkov, V. (2011). Foreign Banks' Entry into the Russian Market: Motivation, Entry Modes and Strategies. Kyoto Institute of Economic Research Discussion paper, No. 801.

Hasan, I., Xie, R. (2012). A note on foreign bank entry and bank corporate governance in China. BOFIT Discussion Paper, No. 8.

Havrylchyk, O. (2011). The Effect of Foreign Bank Presence on Firm Entry and Exit in Transition Economies. BOFIT Discussion Papers, No. 11.

Huang, X., Zeng, Y. (2011). The Impacts of Foreign Bank Entry on Credit Scale and Business Structure of Chinese Commercial Banks. Modern Economy, Issue 2, p. 814-822.

Korobov, Y. I. (2010). Bank competition at the present point. Bankovskoye delo, No. 11, p. 13-16.

Lensink, R., Hermes, N. (2003). The Short-Term Effects of Foreign Bank Entry on Domestic Bank Behaviour: Does Economic Development Matter? Available at: http://www.rug.nl/staff/c.l.m.hermes/foreign_banks_and_economic development.pdf

Li, W. (2011). Effects of Foreign Banks Entry on Efficiency of Chinese Commercial Banks. Available at: http://isi2011. congressplanner.eu/pdfs/950120.pdf 
Liuhto, K., Sorg, M., Uiboupin, J. (2006). Foreign Banks Entry and Bank Performance in the CEE Countries. Banks and Bank Systems, Vol. 1, Issue 3, p. 41-59.

Mamonov, M. E. (2010). Non-structural approach to evaluating the level of bank competition in Russian banking sector. Bankovskoye delo, Vol. 11, p. 17-24.

Mamonov, M. E., Pestova, A. A., Solntsev, O. G. (2011). The banking system of Russia on the way out of the crisis. Bankovskoye delo, Vol. 5, p. 21-31.

Mamonov, M. E., Solntsev, O. G. (2009). Expansion of Foreign Banks into the Russian Market for Banking Services: Interim Results, Tentative Prospects. The Journal of New Economic Association, Vol. 1-2, p. 175-189.

Miklaszewska, E., Mikolajczyk, K. (2009). Foreign Bank Entry and Bank Performance in Poland: Testing the Global Advantage Hypothesis. Journal of Money, Investment and Banking, Vol. 10, p. 57-78.

Pozzolo, A. F. (2008). Bank cross-border mergers and acquisitions (Causes, consequences and recent trends). Economics \& Statistics Discussion paper, Vol. 08/48.

Raihan, A., Morium, S. (2000). Foreign Bank Penetration In Bangladesh: is it Too Bad to Lose Market Share? Bank Parikrama, Vol. 15, No. 1, March.

Rodrigues de Paula, L. F. (2003). The Determinants of Recent Foreign Bank Penetration in Brazil. Cepal Review, Issue 79 , p. 159-176.

Singh, K. (2006). Entry of Foreign Banks in India and China: A Brief Note. Available at: http://www.madhyam.org.in/ admin/tender/Entry\%20of\%20Foreign\%20Banks\%20in\%20India\%20and\%20China, \%20A\%20Note.pdf

\section{UŽSIENIO BANKŲ EKSPANSIJOS ITAKA REGIONINIŲ FINANSŲ RINKŲ PLÉTRAI}

Anna Kladova, Liudmila Parfenova, Vytautas Juščius

Akcinè bendrovė „Rosgosstrakh“ (Rusija), Jaroslavlio valstybinis universitetas (Rusija),

Klaipėdos universitetas (Lietuva)

\section{Santrauka}

Sparti pasaulinės ekonomikos globalizacija skatina liberalizuoti nacionalinių ūkių finansų sistemas. Rinkų liberalizavimas ypač ryškus bankų sektoriuje. Bankų skverbimasis į kitų šalių ekonominę veiklą ypač paspartejo per pastaruosius du dešimtmečius. Bankus labai domino naujos Azijos, Lotynų Amerikos, Centrinès ir Rytų Europos finansų rinkos. Bankų skverbimosi į kitų šalių rinkas būdai regionuose skyrèsi, nes tai lėmè skirtingi šių regionų veiksniai. Savo veiklą užsienyje siekè plètoti dideli bankai, reziduojantys atviros ekonomikos šalyse, kur išplètota finansų sistema. Paplitęs issigijimo ir susiliejimo būdas - dukterinių bendrovių ir filialų steigimas užsienio šalyse. Užsienio bankų ekspansija akivaizdžiai paveikè bankų sektoriaus konkurencinę aplinką, vietinių bankų ekonominès veiklos rezultatus, smulkaus bei vidutinio verslo kreditavimo sąlygas. Galima pastebèti, kad stiprių užsienio bankų atèjimas į šali padidina jos finansų sektoriaus efektyvumą, stabilumą, pelningumą, kapitalizacijos lygị ir konkurenciją bankų sektoriuje. Vis dèlto finansų sektoriaus internacionalizacija turi ir neigiamų padarinių. Užsienio bankai silpnina vietinės kilmès bankų pozicijas, jų veiklą sunkiau kontroliuoti nacionalinės ekonominès politikos instrumentais, padidėja finansų krizių, kilusių kitose šalyse, eskalacija.

PAGRINDINIAI ŽODŽIAI: užsienio banku skverbimasis, naujos rinkos ekonomikos šalys, banku konkurencija, banku sektoriaus stabilumas.

JEL KODAI: G21, G32 